\title{
A Fault in Our Stars: Competitiveness among Michelin-star Restaurants
}

\author{
Ilona Miklós
}

Corvinus University of Budapest

\section{THE AIMS OF THE PAPER}

Hospitality is a creative industry. A national cuisine may contribute to a country's competitiveness by considering the various elements of sustainability in a region, stimulating economical development, and improving the national image. In Europe, the Michelin Star system is the most respected ranking system for high-quality or haute cuisine restaurants. This research is based on whether the characters of Hungarian cuisine can be identified by domestic fine-dining representatives.

\section{METHODOLOGY}

Using qualitative research and content analysis methodology, the paper explores whether fine-dining professionals and Michelin Star restaurants can identify local gastro culinary in the public dialogue.

\section{MOST IMPORTANT RESULTS}

Prizing a Michelin Star could be an innovative or sustainable business strategy, meeting as it does the gastronomic expectations of tourists. Providing a theoretical framework of the relevant literature on the role of innovation within the gastronomy industry, this paper analyses interviews collected from an online media platform. Although not all are covered in this paper, location, co-working, wellbeing and existential balance, inspiration, and burnout are factors identified during the research, factors that could drive Hungarian cuisine in a different direction than others in the international field.

Keywords: gastronomy, sustainability, content analysis 


\section{INTRODUCTION}

Gordon Ramsay, awarding Michelin Stars for the UK \& Ireland 2019, described the event as the „Oscars of the restaurant industry" (HeightonGinns 2018). Basque and Catalan cuisines are more acknowledged than the Spanish (Andrews 1997). Tuscan hospitality and culinary delights are special treats for those visiting Italy (Kivela \& Crotts 2006). Foreign chefs with Michelin Stars are independent brands, competitive partners, and TV stars. At home, many Hungarians claim that although theirs is a small nation, the cuisine is world famous (Molnár 2012).

Fine-dining restaurants are full-service restaurants with refined and delicately assembled cuisines, specializing in dinner-based meals costing $~ € 50$ 70. They are characteristically high-end, luxury, upscale restaurants with elaborate and intentional decor and furnishing. Fine-dining is stable and less responsive to negative trends. In general, they are lower volume than quick-service restaurants, while still generating comparable revenue.

This study aims to find major characteristics of socio-spatial levels of the Hungarian fine-dining sector to discern creative industry patterns. Various forms of culinary globalization processes have been defined by chefs and locations in the fine-dining sector worldwide. But is the Hungarian fine-dining sector stable and responsive to global trends?

The development process of Michelinstarred chefs has similarities and differences to traditional concepts of new product development (Harrington et al. 2014). This combination of global factors is new to hospitality as a creative industry and their existence/absence influence the success of the Michelin Star restaurants and their ability to compete in the local market.

The successful adaptation of economically useful knowledge is an important opportunity in making the hospitality industry more competitive (Ottenbacher \& Gnoth 2005, Töröcsik 2010), while competitiveness guarantees constant reformation and innovation (Harrington 2004). But not everyone can adapt this economically crucial knowledge within the industry.

This study aims to find major variables that define the characteristics of Michelin Star restaurants, assessed by professionals. It focuses on the roles that professional engagement in gastronomy and company location play in relevant knowledge transfer in Hungary, and the influences on the heterogeneity of consumption in fine-dining restaurants.
Taking interdisciplinarity into consideration, Section 1 introduces the creative fine-dining hospitality industry. Section 2 presents regional characteristics of deterritorial structural shaping factors. Section 3 offers an overview of theoretical frames of innovation and creativity. Section 4 introduces a methodological description and qualitative content analysis. Section 5 discusses interviews with 25 selected chefs, owners, and investors in Hungarian top gastronomy. Section 6 concludes with the interpretation of results, the research limitations, and potential future research options.

\section{THEORETICAL FRAMEWORK}

Many disciplines are interested in the academic approach to food and eating out. Interdisciplinary research encompasses anthropology (Elias \& Hammer 1939, Lévi-Strauss 1968, Douglas \& Khare, R. 1979, Appadurai 1981) which sees eating habits as expressive tools of cultural relationships, sociology (Mennell 1996, Bourdieu 1979) and marketing (Törőcsik 2010, 2011, 2016) which examine different socially constructed narratives.

\section{Creative industry}

The fine-dining hospitality industry sees itself as part of the creative economy. The creative economy is basically the triad of creative industries, cultural industries, and knowledge-intensive industries. The creative industry has two main strategies (Zarlenga et al. 2016):

1. The concentration emerging from the so-called cultural or creative industries (film, radio, television), web design, textiles, graphics, fashion, advertising, photography, and architecture (Scott 2000).

2. The developed strategy, which aims to establish cultural services in settlements to attract tourism and related enterprises by regaining the existing heritage (urban regeneration), by setting up cultural institutions (e.g. museums), or organizing big events. 


\section{Figure 1: The frame of Michelin stars}

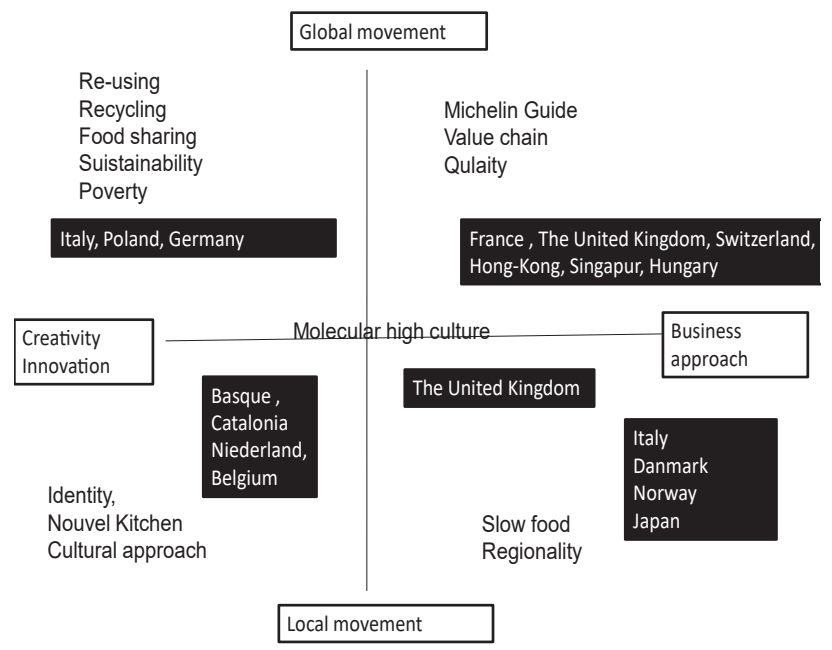

Source: own edition

They both treat innovation and knowledge creation processes in their contexts, i.e., they do not separate them from their true, spatial economic and social processes (Figure 1).

According to Prahalad and Ramaswamy $(2004,5)$, "The meaning of value and the process of value creation are rapidly shifting from a productand firm-centric view to personalized consumer experiences." The market advantage of hospitality depends on whether it stays in or falls out of the net of value creation processes. Competitiveness and innovation are inseparable, but the trend we see relates to the appreciation of international reputation and its accompanying positive impacts. These go beyond the new or significantly improved product, service, or process.

\section{Fine dining}

The French term "haute cuisine" literally means "high cuisine" or "excellent cuisine." It is characterized by unique and particular preparation, processes, and serving modes. In the 1970s, in line with the French dominance of gastronomy, haute cuisine meant "la nouvelle": new cuisine that went against mainstream traditions, including new cooking methods, recipes, and ingredients, still influenced by great French gastronomical traditions (Giuri \& Mariani 2006). Today, haute cuisine covers higher levels of gastronomy, separating these from traditional segments of hospitality (Bojanic \& Rosen 1994).
The English-speaking world embraced the English version of the term - fine dining - which is applied to Michelin Star restaurants to distinguish them from casual-traditional dining. Since the first Michelin Guide or Guide Rouge published in 1900, it has been the world's leading evaluation system (Surlemont \& Johnson 2005). Anonymous reviewers visit all segments and price categories of the hotel and hospitality industry. The number of stars ranges from 1 to 5 and plays a significant marketing role. Losing a star could result in as much as a $50 \%$ setback (Surlemont \& Johnson 2005) in terms of sales.

While fine dining is a vibrant, expansive niche sector of the global restaurant market, consumer values are shifting towards convenient eating and restaurants are evolving their menus to accommodate. Compared to $2016,37 \%$ of diners are now looking for value-priced meals (Technomic 2018), Millennials (46\%) in particular are hungry for deals. As diners increasingly associate eating out with an opportunity to post on social media, restaurants race to remodel stores to boost the "experience" factor. Front-of-house design has Instagram in mind, and consumers expect more from the restaurant than just a good meal. 


\section{Globalization of culture}

Globalization plays a significant role in creating and transforming different economic, social, and environmental processes. Economic and social structural changes in turn lead to spatial and environmental changes (Rechnitzer - Lengyel 2000). Investor behaviour is constantly evolving and changing along the centre-periphery of power relations, contributing to the transformation of traditional consumption and lifestyle.

The globalization of culture as a movement of symbols, styles, and practices over an extended space, has been portrayed as highly pervasive (Appadurai 1990). It takes several contrasting forms. Cook and Crang $(1996,137)$ use the globalization of culture to distinguish the local. In contrast, the pluralization of cultural styles and competition between them is more likely to marginalize the local. Pieterse $(1995,49)$ defines the hybridization of cultural forms as separated from existing practices. Tomlinson (1999) refers to the process of local cultural resistance as re-territorialization.

\section{International directions of stars}

\section{Molecular high culture}

The traditional Spanish food renewal movement started in the 1970s in the Basque territory, where chefs interpreted/translated French nouvelle cuisine ideas into Basque, and named it Nueva cocina vasca (New Basque kitchen) (Andrews 1997). Ferran Adrià, a Catalan chef was named as one of the ten most remarkable innovators in 2004 by Time magazine (Graff 2004). In the scientific cooking style he introduced in El Bulli, he merged molecular science with culinary practice (Svejenova et al. 2007). Thus molecular gastronomy became a new and accepted cooking style. Adrià's success affected the cooking style of leading Spanish chefs who now often associate themselves with molecular gastronomy. His success revolutionized Spanish cuisine. Using scientific knowledge has become a pillar of Spanish creativity, where the focal point is the innovation of new raw materials, techniques, and ideas. "Cooking is a language through which all the following properties may be expressed: harmony, creativity, happiness, beauty, poetry, complexity, magic, humour, provocation, and culture" (Adrià et al. 2005). Adrià was invited to Kassel, to the forum of contemporary arts, where modern cuisine was introduced as a factor of the genre. Magazines now write about El Bulli in their culture columns, starting a dialogue between gastronomy and other forms of art.

\section{Slow food and food share}

Massimo Bottura's Osteria Francescana longknown for its philosophy of "cooking is sharing" tops the "World's 50 Best Restaurants List." Donating and sharing food is a cultural project, i.e., an organic part of the creation and the process (Tonon 2016). Counteracting the "fast food" phenomenon, northern regions of Italy are leading the increasingly popular slow-food movement. It focuses on the slow, attentive, traditional, and noble intake of food. Bottura not only speaks (Law 2016) about it but also publicizes the organizational culture of his kitchen conception. The soup-kitchen chain, Refettorios, had an active role in the Rio Olympics, sending leftovers from the Olympic village to the needy. Food for Soul, now a movement, has the support of Michelin Star chefs Alain Ducasse and the Spaniard Joan Roca. Bottura's initiatives aim to have less food end up in the trash (Law 2016) and have the surplus - by minimizing losses and in a re-thought form - reused on the plate, no matter what kind of restaurant(Michelin Star or soup kitchen) the food originated from. He speaks to the public via social media about the concept of reuse and reallocation, attracting supporters (e.g. Robert de Niro), and starting discussions on topics such as the right to good food, the reuse of leftovers, and poverty. "We are not thinking in terms of pop-ups. We plant seed, and our goal is to start growth and cover all of Earth" (Adams 2017).

\section{Tales from the North}

The Scandinavian kitchen concept - New Nordic - was made famous by a Danish kitchen. Restaurant Noma owes its Michelin Stars to René Redzepi and his team, who established creative workshops called food labs or kitchen labs. Experienced chefs from all over the world stand in line to observe and learn in Noma's kitchen. Traditional Scandinavian raw materials and cooking methods are merged with innovative gastronomical thinking, an advantageous combination for Northern chefs competing at the Bocuse d'Or. The unusual ingredients of New Nordic are plated as perfect commodities; even the chefs help gather them. According to Redzepi, everything has a story. While he works on the raw materials in the background, he creates a story out of them, and tells this story at the table. Redzepi believes (Jenkins 2017) that stories need to be 
shared. Only by talking can we find our own stories in food and in life.

\section{Hungarian tradition}

Costes in Budapest received Hungary's first Michelin Star (Index 2010). Three other restaurants have joined this prestigious group of fine-dining restaurants. Civil gastronomical traditions in Hungary stopped after WWII, replaced by the party-state's public catering strategy, resulting in the stereotypical hospitality we experience so widely today. "Volume above all" was the slogan that shaped gastronomical education and industry dialogue. Only large-scale hospitality survived this era for over half a century (Keszeg 2011, Báti 2000, 2008, 2009). Cooperation between professionals within agriculture, the health industry, and environmental protection disappeared from professional kitchens in recent decades. To solve the situation, the Hungarian Gastronomical Association (MGE) launched its gastronomical lobby under the name Culinary Charter 2007 (Kulináris Charta 2007). Its mission is to repair the Hungarian eating culture by shunting negative processes. Thanks to this movement that originates from outside of the profession, in 2019, Costes, Borkonyha Winekitchen, and Costes Downtown, Stand and Babel have one Michelin star, and Onyx has two. Compare this to Austria's 13 one-star and 7 two-star restaurants. Or 2 one-star restaurants in both the Czech Republic and Poland. While Hungary, the Czech Republic, and Poland only boast Michelin-star restaurants in their capitals, Austria's include Salzburg, Hallwang, and Kleinwalsertal.

For the Basque region, the introduction of an independent fine- dining gastronomy contributed to defining its national identity. An Italian Michelin chef is looking for solutions to global issues by introducing poor-kitchens and reusability concepts to the public. The Danes built a two-star Michelin restaurant brand with the help of local stories and limited raw materials. Hungarian cuisine, however, is looking for a breakthrough by separating itself from the mundane, and by redefining traditions with initiatives coming from above (Molnár B. 2012).

\section{Knowledge, creativity, and innovation}

Schumpeter's theory of "creative destruction" (1939) appears as a new combination of production factors which achieves professional development while constantly fighting the environment. According to Schumpeter, the main point of capitalism is the search for innovation opportunities, during which innovation is an aggressive drive to destroy the balance. The environment embodies continuous fight and movement, i.e., "creative destruction", and also creates a dynamic, sensitive selection process.

Schumpeter's five base cases of innovation:

1. Goods yet unknown to new consumers

2. New production processes which are yet unknown in the given industry

3. New placement opportunities, i.e., the opening of new markets

4. New supply sources of raw materials or semi-finished goods

5. Establishment of a new organization or the abolition of an organization.

According to the Oslo Manual innovation activities are "all scientific, technological, organizational, financial and commercial steps which actually, or are intended to, lead to the implementation of innovations (Galindo-Rueda \& Van Cruysen 2016).

Amabile's definition of creativity is "the production of new and useful ideas in any fields" (Amabile et al. 1996, 2). Here, "useful" suggests that an idea can create a short- or long-term increase in value, whereas "novelty" covers all ideas that represent uniqueness compared to those available at the time. Innovation "realizes the successful manifestation of creative ideas within an organization" (Amabile et al. 1996, 2), i.e., innovation cannot manifest itself without some form of creativity.

This paper uses the expression "culinary creativity," which may mean several things in the context of restaurants. It could be related to cooking methods, new flavours and flavour-combinations, smells, visual aesthetics and composition, presentation, or serving. Innovation means fulfilling consumer demand at a new, higher level by consumer orientation, novelty, and uncertainty (Chikán 2017). Krugman (2000) drew attention to the positive externality of access to knowledge noting the knowledge-spillover effect that automatically takes place between companies.

\section{Implementation}

The theoretical literature on the analysis of implementation traditionally distinguishes top-down and bottom-up changes, i.e., programmed and adaptive-evolutionary changes (Darling-Hammond 1998, Fitz et al. 1994). Research related to top-down types of change focuses on the realization of decisions made in the centre. This approach assumes the process to be hierarchical and linear. 
The bottom-up approach emphasizes the importance of the changes starting from below, i.e., local-level implementers, street-level bureaucrats, and local institutions (Fitz et al. 1994).

Research focusing on micro processes, breaking the dominant conception of a top-down perspective that focuses on implementation loyalty, had a significant role in the experiences of the two approaches drawing closer together. As for adaptation opportunities, four so-called implementation trails exist: unsuccessful adaptation, technological adaptation, formal implementation, mutual adaptation.

\section{METHODOLOGY}

The context of this study is fine-dining restaurants in Hungary. Single-industry studies are criticized for being too narrow in scope and presenting problems in generalizing the results and using the findings for theory building. This research methodology uses both manual and electronic qualitative data analysis approaches labelling ,interpretive" research where the researcher is attempting to interpret their meaning. The aim is to focus attention on the researcher and their contribution to the data creation and analysis process.

\section{Qualitative content analysis}

Qualitative content analysis (Mayring 2000) uses several techniques in the systematic analysis of texts, when it looks for the content of the communication in the document. Content analysis is a retrospective research method, based on the exploration of the structure of inner characteristics and context, comparing insights of interviews, and looking for common points and different characteristics during narrative analysis to classify them into groups. Data used in this paper are qualitative. In the qualitative element, 25 plus 3 extra interviews were held with chefs and fine-dinning restaurateurs with different decision-making powers.

\section{Location and date of sampling}

Interviewees were chosen from the list of restaurants, chefs, and hospitality experts awarded in Dining Guide's February 2018 publication for their achievement in 2017.

1. Dining Guide's website is the most frequented, professionally significant portal with its own Facebook profile and its own evaluation system.
2. Albeit in a Hungarian context, its point system and categories are a close match for Michelin's international reputation.

The Chef de Cuisine (Executive Chef) has the most power in the kitchen; they are responsible for food quality, revenue, cost, culture fostering, guest feedback, menu conceptualisation, procurement, and training.

Next is the Sous Chef who is responsible for planning and directing food preparation; ensuring the highest standards and consistent quality in the daily preparation; and keeping current with new products, recipes, and preparation techniques.

The Trainer Chef or Coach is part of the team, too. An R\&D culture with mentoring in the kitchen could reduce staff turnover and motivate the kitchen staff. The Coach is a culinary leadership expert, who outlines the best practices for staff coaching and hospitality skills.

The Lobbyist is an activist seeking to persuade members of the government to enact legislation that would benefit their group. They seek to assert their own alignment of quality conventions through the lobbying efforts of their national organization (Pannon Akadémia) and their affiliation to the Bocuse d'Or.

Restaurant Owners are responsible for the daily operations as well as the overall direction, profitability, and reputation. Some are extremely hands-on, helping out in the kitchen and interacting with customers, while others hire managers and focus on strategic planning. They spend much of their time supervising employees, directing operations, and finding ways to adapt to customers and industry trends.

Executive Chefs who are Restaurant Owners have many years of experience in the restaurant industry. To improve their skills, they have the option of taking workshops and classes or obtaining certifications.

This study is based on the content analysis of 25 interviews: seven Executive Chefs, two Sous Chefs, a Trainer Chef and Coach, a Lobbyist, eight Owners/Investors, and six Executive Chef/Owners. Out of 25 interviews three have business in countryside, others are Budapest based. These 2017 interviews were downloaded from http://www. diningguide.hu between March and May 2018. Data analysis was completed with three interviews with international chefs - Ferran Adrià, Massimo Bottura, René Redzepi - to reflect and value Hungarian data. 


\section{Encoding phase}

Defining the research problem and closely planning the research kills creativity, according to Glaser and Clark (1992), forcing already existing theories onto the result. It does not give space to the solution where the researcher applies a more general approach and lets the research problem be concretized during the research process (Mitev 2012).

NVivo 9.0 was chosen over other packages because it was free. It was used for encoding to define the most frequent expressions and tools of speech in the 25 interviews. First the text was coded into a format NVivo 9.0 could handle. Then a word frequency function was used to choose the texts to be examined. Finally, a filter based on position and operational site was applied to segment samples to sub-groups:

\section{By position}

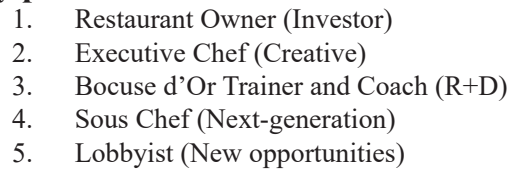

\section{By location}
1. Budapest
2. Countryside
3. International

While processing the content encoded in the first working phase, the system examined whether in the case of a code category, the given occurrence frequencies were repeated. It also examined the most frequently used words and expressions based on occurrence, which was later confirmed by the help of a wordcloud app to make the not yet present expressions (latent content) visible. Because every code symbolizes a meaning, the common occurrence of two or three codes created a "report surplus," which was not present in the original text. Yet here, even the lack of something can become an important content indicator.

\section{Interpretation phase}

Common occurrences in the text suggest laws which can be interpreted. However, it also happens that the document lacked a code (and thus a concept represented by the code) which we would expect in the given content - e.g. because it appeared in similar documents before. In this case, it was found a not present, latent momentum, which could be significant because of its "meaningful disappearance."

\section{RESULTS}

\section{Where should Hungarian gastronomy head now?}

\section{By operational site}

The analysis of the interviews confirmed that Budapest is the focal point of Hungarian gastronomy. It plays a significant role in gastronomy as a geographical location. Budapest hospitality players do not hide their desire to appear on international levels, targeting Austria, Italy, and the USA. In contrast, international chefs generally define their home country as a reference, and the region, city or town where their enterprise is based (e.g. Dortmund, Bologna).

Unlike those in Budapest, investors in the countryside are aware of the reality outside of Budapest. Restaurant owners and chefs also mention Miskolc, Nyíregyháza, Kassa, Balatonszemes, Pannonhalma, and Györ among the settlements close to their HQ. One of the chefs has a tattoo with the GPS coordinates of Györ, so as not to forget where he started off. For Hungarian restaurant owners and chefs, Spanish and Italian examples are the main attractions in terms of international expertise.

\section{By position}

Restaurant owners and investors focus on industry, profession, and sector instead of geographical regions, while chefs look for parallels with US one-star Michelin counterparts

The Lobbyist would like to gain more insight into the operation of two-star restaurants, to see what takes a restaurant to the top. Surprisingly the lack of next-generation chefs and raw materials does not concern them; they focus on potential political connections and strategic partnerships both domestic and foreign.

Chefs and owners who have already travelled the road towards a Michelin Star and taken part in the Bocuse d'Or internationally, highlight regionality and the importance of workshops when talking about international experiences. 


\section{What goals should hospitality set?}

Permanent and readily available ingredients as well as a skilled, dedicated workforce are the main obstacles to development.

\section{By working site}

Budapest chefs create fabulous food of the highest quality, while those in the countryside focus on average, family-friendly delicacies in restaurants where guests and staff know each other. Here, making a mistake would adversely affect the business in the long run. Foreign chefs look at food as a creation, with a philosophy. For the needy, the food is an experience, just like a painting. Hungarian hospitality experts agree on the need to cooperate more closely with wineries and wine regions.

\section{By position}

Investors would like to see a concept that serves long-term expectations in fantastic restaurants, where risk-taking is tolerable and the restaurant provides an attainable service for those affected.

Chefs mainly imagine rational gastronomy in Hungary, where food is created from top-quality ingredients for international guests, with clearly identified methods and a financially stable business model. The best combination is outstanding food with good service.

The Lobbyist's main goal is to reach the twostar Michelin level, their determinant of success.

When it comes to the next generation, the primary task seems to be effectively addressing young aspirants. They get their opportunities from the owners, therefore the experts trust that the next generation of chefs will be just as important for the entrepreneurs in the future as international recognition is right now.

\section{How will fine dining achieve the goals set?}

Besides the geographical or location aspects of content analysis, we need to examine the verbs, i.e., how the participants imagine the realization of their plans.

\section{By operational site}

Those in the countryside see practical ways to reach their goals. They share experiences among themselves that enable them to pursue new ways. For those in Budapest, dialogue is important in building networks, but without unique contacts, development is inconceivable.

International chefs think of responsible practice. They also taste everything and if possible, take part in charitable initiatives. Encourage, motive, and taste are verbs which suggest stability and safety besides getting acquainted with the novelties of innovation.

Investors see themselves as objective bystanders. When it comes to verbs, they mainly use conditionals: would like to, would repair, would try. They do not take risks or side-effects casually.

The Lobbyist, for whom strategic networking is important, mainly focuses on tasks and action. When it comes to methods, he is more likely to deal with those he agrees with.

Chefs are dedicated and do their best to move on after failures. They have a practical approach to realizing their visions, and prefer automatic, regular tasks.

For the next generation, a mentality based on recognition is ideal. They believe in workshops and values brought from home. Other important aspects are the role of the father and their intention to make him proud.

\section{CONCLUSION}

Fine dining is a creative industry consisting of a diverse group of people working together under one roof and in one kitchen. Managing the front-ofhouse (customers) and the back of the house (employees) is not easy. But can Hungarian cuisine characteristics can be identified by finedining representatives? Could the global culinary cultural innovation performance of Hungarian fine-dining hospitality be recognized in domestic public dialogue?

Interview analysis confirms that in Hungary, Budapest is the gastronomic focal point. There is little competition between locations; the rural area is more likely to be marginalized. New processes and technological skills are helping, but the innovative organizational theories lack financial and raw ingredient resources. While foreign chefs look at food as a creation, which has coherent characters or well-built stories with a philosophy, the content analysis of the top 25 Hungarian interviewees 
shows that there is much discussion about possibilities such as new business concepts or reform, but this does not lead to action. Among hospitality entrepreneurships, even if they set a Michelin
Star(s) as a goal, their needs and expectations are different, which does not guarantee success at system level in the long run.

\section{Figure 2. Period of competetiveness and innovation}

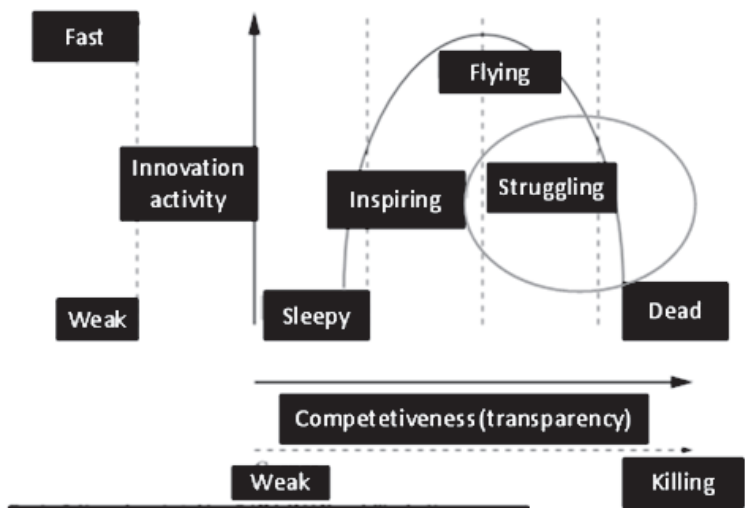

Source: Aghion and Griffith (2005)

Different stakeholders have different perceptions of Hungarian cuisine with no common thought as to how to promote it internationally. It seems no unified conception or possibility for discussion exists which could result in defining a breaking point to catch up with the Michelin Star owners' club in the long run.

\section{Validity and reliability}

Kirk and Miller (1986:21) suggest that validity in qualitative research "is ... a question of whether the researcher sees what he or she thinks he or she sees" so that there is evidence in the data for the way in which data is interpreted. Qualitative data analysis is "impression analysis" because of the lack of detail and scrutiny of how the analysis process itself is carried out.

\section{Limitations of this study}

The scope of analysis is limited to the high-end fine-dining category and the Michelin Star segment of the hospitality industry. It aims to understand the embeddedness of innovation in terms of culinary creativity, and how the results apply to the Hungarian gastronomical environment. Yet during the research process, secondary foreign sources were used, some related to other regions because like other industries, hospitality is becoming more and more global. 


\section{HIVATKOZÁSOK}

Adams, T. (21/05/2017), ,Massimo Bottura and his global movement to feed the hungry", https:// www.theguardian.com/lifeandstyle/2017/ may/21/massimo-bottura-feed-the-hungryfood-for-soul The Guardian Online [accessed 10/15/2018]

Adrià, F, Sorel, J., Adrià A. (2005), F. El Bulli 1998-2002, Ecco, London

Amabile, T. M., Conti, R., Coon, H., Lazenby, J., Herron, M. (1996), ,Assessing the Work Environment for Creativity", Academy of Management Journal 39 5, 1154-84 DOI: https://doi. org/10.2307/256995

Andrews, C. (1997), Catalan Cuisine: Europe's Last Great Culinary Secret, Grub Street Cookery

Appadurai, A. (1981), "Gastro-politics in Hindu South Asia", American Ethnologist, 8 3, 494-511 DOI: https://doi.org/10.1525/ ae.1981.8.3.02a00050

Appadurai, A. (1990), „Disjuncture and difference in the global cultural economy," Theory, culture \& society, 7 2-3, 295-310. DOI https://doi. org $/ 10.1177 / 026327690007002017$

Báti A. (2000), „A lakodalmi étrend, ételek változása 1941-1996." in: Herman Ottó Múzeum Évkönyve XXXIX. 481-96

Báti A. (2008), Régi és új elemek a cserépfalui konyhán, Budapest: Magyar Néprajzi Társaság

Báti A. (2009), „A jól felszerelt konyha. Kell ma még tudni fözni?" Ethnographia, 120, 255-66

Bojanic, D. \& Rosen, D. (1994), "Measuring service quality in restaurants: An application of the SERVQUAL instrument", Hospitality Research Journal, 18 3-14 DOI: https://doi. org/10.1177/109634809401800102

Bourdieu, P. (1979), "Symbolic power", Critique of Anthropology, 4 13-14, 77-85 DOI: https://doi. org/10.1177/0308275x7900401307

Chikán A. (2017): Vállalatgazdaságtan, 5. kiadás. VTOA, Budapest.

Cook, I., \& Crang, P. (1996), „The world on a plate: culinary culture, displacement and geographical knowledges", Journal of material culture, 1 2, 131-53 DOI: https://doi. org/10.1177/135918359600100201

Darling-Hammond, L. (1998), "Policy and change: Getting beyond bureaucracy", In: Hargreaves A., Lieberman A., Fullan M., Hopkins D. (eds) International Handbook of Educational Change. Springer, Dordrecht DOI:https://doi. org/10.1007/978-94-011-4944-0 32

Douglas, M. and Khare, R. S. (1979), "Commission on the anthropology of food: statement on its history and current objectives", Information (International Social Science Council), 18 6, 903-13 DOI: https://doi. org/10.1177/053901847901800606

Elias, N. and Hammer, H. (1939). Über den Prozeß der Zivilisation. Vol. 2, pp. 367-367. Suhrkamp.

Fitz, J., Halpin, D. and Power, S. (1994), "Implementation research and education policy: practice and prospects", British Journal of Educational Studies, 42 1, 53-69 DOI: https://doi.org/ 10.1080/00071005.1994.9973983

Galindo-Rueda, F. and Van Cruysen, A. (2016), „Testing Innovation Survey Concepts, Definitions and Questions: Findings from Cognitive Interviews with Business Managers", OECD Science, Technology and Innovation Technical Paper, Paris. DOI: https://doi.org/10.4337/9780 857933652.00019

Graff, J. (26/04/2004), Our list of the most influential people in the world today, Artists \& Entertainers Ferran Adrià. The Time Online http:// content.time.com/time/specials/packages/article/0,28804,1970858_1970890_1971358,00. html [accessed 10/15/2018].

Giuri, P. and Mariani, M. (2006), Everything you always wanted to know about inventors (but never asked): Evidence form the PatVal-EU survey (No. 2005/20). LEM Working Paper Series 1-36

Glaser, M. A. and Clark, N. A. (1992), "Melting and liquid structure in two dimensions", Advances in chemical physics, 83 543-709 DOI: https:// doi.org/10.1002/9780470141410.ch7

Harrington, R. J. (2004), "The environment, involvement, and performance: implications for the strategic process of food service firms", International Journal of Hospitality Management, 23 4, 317-41 DOI: http://dx.doi. org/10.1016/j.ijhm.2003.12.004

Harrington, R., K. Chathoth, P., Ottenbacher, M., \& Altinay, L. (2014), „Strategic management research in hospitality and tourism: past, present and future", International Journal of Contemporary Hospitality Management, 26 5, 778-808 DOI: http://dx.doi.org/10.1108/ijchm-12-20130576

Heighton-Ginns, Laura: (12/10/2018) The business behind Michelin stars. https://www.bbc. com/news/business-45733941 BBC Online [accessed 03/10/2019].

Jenkins, A. (17/09/2017), "Nadine Levy Redzepi: What do you cook for the world's best chef?" https:/www.theguardian.com/lifeandstyle/2017/sep/17/nadine-levy-redzepi-nomawhat-to-cook-for-the-worlds-best-chef The Guardian Online [accessed 10/3/2019]

Keszeg, V. (2011), „Gasztronómia és emlékezet”, Erdélyi Múzeum, 73 1, 177-88

Kirk, J., Miller, M. L. (1986), Reliability and validity in qualitative research (Vol. 1), Sage, DOI: http://dx.doi.org/10.4135/9781412985659 
Kivela, J. \& Crotts, J. C. (2006), „Tourism and gastronomy: Gastronomy's influence on how tourists experience a destination", Journal of Hospitality \& Tourism Research, 30 3, 354-77 DOI: https://doi.org/10.1177/1096348006286797

Krugman, P. R. (2000), "Technology, trade and factor prices", Journal of International Economics, 50 1, 51-71 DOI: http://dx.doi.org/10.1016/ s0022-1996(99)00016-1

Law, K. (13/10/2016), "Italian super-chef Massimo Bottura on the power of leftovers", https://www. standard.co.uk/lifestyle/london-life/italian-superchef-massimo-bottura-on-the-power-of-leftovers-a3368331.html Standard U.K. Online [accessed 10/15/2018]

Lévi-Strauss, C. (1968). L'Origine des manières de table (1968, The Origin of Table Manners, trans. John Weightman and Doreen Weightman, Harper \& Row, Publishers, New York, 1979). pp: 284-310;

Magyar Gasztronómiai Egyesület (MGE) Kulináris Charta 2007/06/09 https://www.buvosszakacs. com/kulinaris-charta/ [accessed 10/15/2018]

Mayring, P. (2000), „Qualitative Content Analysis“, Forum Qualitative Sozialforschung / Forum Qualitative Social Research, $12 \mathrm{http}: / / \mathrm{www}$. qualitative-research.net/index.php/fqs/article/ view/1089/2385\%3E

Mennell, S. (1996), All manners of food: eating and taste in England and France from the Middle Ages to thpresent, University of Illinois Press, DOI: https://doi.org/10.2307/590730

Michelin-csillagot kapott a Costes étterem (2010.03.16.) https://index.hu/kultur/elet$\bmod / 2010 / 03 / 16 / \mathrm{megvan}$ az_elso_magyar_michelin-csillagos_etterem/ $/$ [accessed 21/01/2019].

Mitev, A. Z. (2012), „Grounded theory, a kvalitatív kutatás klasszikus mérföldköve", Vezetéstudomány, 43 1, 17-30

Molnár B. T. 01/30/2012), A magyar konyha nem világhírü http://hir6.hu/cikk/61887/molnar_b tamas a magyar konyha nem vilaghiru [accessed 12/15/2018]

Ottenbacher, M. and Gnoth, J. (2005), "How to develop successful hospitality innovation", Cornell Hotel and Restaurant Administration Quarterly, 46 2, 205-22 DOI: https://doi. org/10.1177/0010880404271097

Pieterse, J. N. (1995), "Globalization as Hybridization", In M. Featherstone, S. Lash, \& R. Robertson (Eds.), Global modernities (45-68), Thousand Oaks, CA: Sage DOI: http://dx.doi. org/10.4135/9781446250563.n3
Prahalad, C. K. and Ramaswamy, V. (2004), "Co-creation experiences: The next practice in value creation", Journal of Interactive Marketing, 18 3, 5-14 DOI: https://doi.org/10.1002/ dir. 20015

Rechnitzer J. - Lengyel I. (2000), „A városok versenyképességéröl”, In: Rechnitzer J. - Horváth Gy. (szerk.): Magyarország területi szerkezete és folyamatai az ezredfordulón. MTA Regionális Kutatások Központja, Pécs, 130-52

Schumpeter, J. A. (1939), Business cycles Vol. 1. New York: McGraw-Hill

Scott, A. J. (2000). The cultural economy of cities: Essays on the Geography of ImageProducing Industries, Sage. DOI http://dx.doi. org/10.4135/9781446217481

Surlemont B, Johnson C.. (2005), "The role of guides in artistic industries: The special case of the "star system" in the haute-cuisine sector", Managing Service Quality: An International Journal, 15 6, 577-90 DOI: http://dx.doi. org/10.1108/09604520510634032

Svejenova, S., Mazza, C. and Planellas, M. (2007), "Cooking up change in haute cuisine: Ferran Adrià as an institutional entrepreneur", Journal of Organizational Behavior: The International Journal of Industrial, Occupational and Organizational Psychology and Behavior, 28 5, 53961 DOI: http://dx.doi.org/10.1002/job.461

Technomic (2018), 2017 Value \& Pricing Consumer Trend Report (Winsight LLC.) https:// www.technomic.com/available-studies/ consumer-trend-reports/value-and-pricing [accessed 3/10/2019]

Tomlinson, J. (1999). Globalization and culture. University of Chicago Press.

Törőcsik M. (2010), „Életstílust kifejező ételfogyasztás, a food-trendek hatása", Korunk, 3, 58-65

Törőcsik M. (2011), Fogyasztói magatartás: Insight, trendek, vásárlók, Akadémiai Kiadó

Törőcsik M. (2016), „A fogyasztói magatartás új tendenciái”, Vezetéstudomány - Budapest Management Review, 47 4, 19-25

Zarlenga, M. I., Ulldemolins, J. R. and Morató, A. R. (2016), "Cultural clusters and social interaction dynamics: The case of Barcelona," European Urban and Regional Studies, 23 3, 422-40 DOI: https://doi.org/10.1177/0969776413514592

Miklós Ilona, PhD hallgató ilona.miklos@uni-corvinus.hu Budapesti Corvinus Egyetem Gazdálkodástudományi Kar 